\title{
Literatura, historia: crisis de las disciplinas y contextos para la ficción
}

\section{Literature, history: crisis of disciplines and contexts for fiction}

\author{
Pilar García \\ Universidad de Chile \\ pilargarcia.pg@gmail.com \\ ORCID iD: http://orcid.org/0000-0003-4371-4460
}

\section{RESUMEN}

El artículo retoma la pregunta por el lugar de la literatura; en cuanto textualidad retórica; así como el de la ficción; en cuanto facultad ontológica de los discursos, en un momento de crisis de conceptos como 'trama', 'historia' y 'relato'. La revisión contemporánea de categorías como el 'afuera de la historia', o la de 'ficcionalización' de los discursos (literarios, históricos, políticos, epistemológicos), señalan una primacía de la llamada configuración poética (poiesis) en un momento definido como posterior al giro lingüístico. Bajo este ámbito de discusión, el estudio se centra en el problemático asunto de los grados de historicidad, entendidos como grados de intervención de lo real en la ficción, cuando esta última se presenta más problemática que las identificaciones habituales de lo real-histórico (representación).

Palabras Clave: referente; ficcionalización; literatura e historia; relato; ficción histórica; narración.

\begin{abstract}
The paper takes up the question about the place of the Literature; as a rhetorical textuality, as well as the fiction; as ontological faculty of the speeches, in a critical time of the concepts like 'plot', 'history' and 'narrative'. The contemporary review of categories such as 'outside of history' or the 'fictionalization' of the speeches (literaries, historicals, politicals, epistemics), points to a primacy of the well-known poetical configuration (poiesis) in a moment after to the linguistic turn. In this scope of discussion, the study focus in the problematic issue of the degrees of historicity, known as a intervention degrees of reality in fiction, when the fiction appears more problematic than the usual identification of the real-historic (representation).
\end{abstract}

Key words: Referent; Fictionalization; Literature and History; Narrative; Historical fiction; Narrative. 
Es, de golpe, la posibilidad misma de la representación de ese pasado sin testigo lo que resulta arruinada

(Chartier 2005: 85)

Si bien problemáticas, las relaciones entre literatura e historia no dejan de ser sugerentes. Tal vez ello se deba a la ambigüedad de sus fronteras, así como a las interrogantes y reformulaciones suscitadas por dichos vínculos, en los que confluyen disciplinas humanas y sociales diversas, con sus correspondientes tradiciones conceptuales, metodologías y crisis internas. Una mirada de cierta amplitud sobre estos discursos no espera resultados concluyentes, nomenclaturas fijas o teorías absolutas; muy por el contrario, «descifrar, confrontar y traducir» (Perus 1994: 7) aparecen como las operaciones que identifican con mayor claridad esta búsqueda, comunes a la actividad del historiador y del literato.

El estudioso de la literatura, después de los años cincuenta y sesenta, gracias al influjo de la sociología de la literatura, las teorías de los contextos y de los actos de habla, ha echado mano a documentos y archivos - conocidas fuentes históricas - para situar y reconstruir la composición literaria, determinar las influencias externas de la significación y observar los procesos de lectura. A fin de cuentas, los métodos de la historia han sido corolarios exigidos al literato para desarrollar sistemáticamente su disciplina.

Las estructuras literarias entran en correlación con las estructuras históricas y sociales; las lecturas se desgastan, se reactivan, cambian de lenguaje, permanecen. H. R. Jauss se refirió a las provocaciones o desafíos de la historia literaria a la ciencia literaria ${ }^{1}$; en que historizar la recepción de la literatura requiere de un proceso inclusivo e interdisciplinario: inclusivo, en relación a los métodos de lectura e interpretación de los textos literarios - sean estos métodos estructuralistas o no- e interdisciplinario, en cuanto requiere la asesoría de metodologías, en primera instancia históricas ${ }^{2}$ : las historias literarias proponen una cronología, relacionan e interpretan, así como el criterio generacional construye modelos de consecución natural en la creación; los cuales, a su vez, indirectamente canonizan ${ }^{3}$. Sin embargo, una de las mayores críticas a la historia literaria es la de mantenerse ajena a las crisis y debates al interior de la histo-

${ }^{1}$ Esta es una de las primeras críticas a las pretensiones científicas de los estudios literarios y a la inmanencia de la obra literaria (Jauss 1976 [1967]).

2 En primera instancia, históricas, pues la antropología y la etnología han comenzado a ser necesarias para conocer e instalar, con grados de validez y legitimidad aceptables, literaturas como la mapuche, por ejemplo.

3 Tanto el criterio generacional como las historias literarias responden a una construcción de índole ideológica y cultural compleja, con esto me refiero a la construcción de cánones literarios y bajo ellos, a una serie de rótulos, etiquetas y categorías que permitirían 
riografía, así como haber olvidado la «vida histórica» del sistema literario (Kushner 1994).

La literatura no solo ha tendido puentes con la historia cuando configura una obra poética, recurriendo a «fuentes» — documentos, archivos, investigación de diversa índole en función de la verosimilitud-; sino también en la actividad misma del estudioso. ¿Hasta qué nivel el investigador y estudioso de la literatura «actúa» o «performa» como historiador? ¿Cuáles son los textos con que se enfrentan historiadores y literatos? Sin duda, textos de carácter heterogéneo en términos de sentidos, significaciones, géneros y condiciones de enunciación y recepción, cuya diferencia central estriba en ser literarios o no literarios. La nítida demarcación entre estos textos entregaría las pautas de las operaciones realizadas por ambas disciplinas, pero reduciría los vínculos entre ellas a un mero intercambio de informaciones y procedimientos textuales:

Las obras literarias representarían para el historiador un tipo de "documento" particular, más bien poco fiable debido a su carácter ficticio y a las ambigüedades de su lenguaje, mientras que para el literato la historia proporcionaría los elementos de información necesarios al esclarecimiento de aspectos secundarios (referenciales y no propiamente artísticos) de las obras estudiadas (Perus 1994: 8).

Sin embargo, la distinción entre textos literarios y no literarios ya concita un problema de definición de términos no del todo claros tras las revisiones críticas del formalismo ${ }^{4}$ y el surgimiento de las teorías del discurso y del contexto, teniendo como base la crisis de la referencialidad y de los límites de la ficción, agenciada por las vanguardias artísticas. Las cualidades de «permanencia» $\mathrm{y}$ «universalidad», propias de la literatura y el arte, caracterizadas en gran medida por su ahistoricidad, son sometidas a revisión, reinstalando estos conceptos en el tiempo.

El deslinde entre literatura e historia ha operado como sustrato a los actuales debates en torno a la «función estética» o la «especificidad» literaria. En tanto se llega a la conclusión de que no es posible explicar las tensiones y tránsitos entre literatura e historia a través de dicotomías o posiciones maniqueas. Basta recordar que la historia moderna es fundada entre los siglos XVIII y XIX, indicando el paso de la historia tradicional, entendida como «relato de sucesos memorables» de un pasado cercano o lejano, a una disciplina dedicada

ubicar, incluir, excluir, comprender y «leer» las diversas obras —o discursos - literarios producidos por una comunidad — nacional o continental, étnica o social-.

${ }^{4}$ La distinción formalista entre habla coloquial y habla poética condujo a malentendidos en relación a los límites entre literatura y no literatura. Los trabajos de Teun A. van Dijk (1998) relativizaron en gran medida estas restricciones ajenas a las realizaciones efectivas del habla. La falta de una conceptualización abarcadora para el fenómeno del habla condujo a que este fuera relevado por el de discurso. 
a reconstruir y explicar «objetivamente» procesos y acontecimientos del pasado. Este paso funda la distinción entre historia y relato.

Mientras, los lugares de contaminación aumentan cuando se instala la perspectiva temporal, pues el pasado es reclamado como referente y materia narrativa tanto de la historia como de la literatura. En un segundo nivel, la relación que el literato establece con las obras es una relación con el pasado entendido como tradición.

\section{FICCIONALIDAD}

Las pretensiones científicas alcanzadas por la literatura a principios del siglo XX, al alero de la lingüística estructural, la definen como fenómeno estético de lenguaje, inmanente y autorreferente, con un «objeto» de estudio definido, regido por reglas propias, capaces de configurar mundos posibles autónomos, análogos a la realidad; con una terminología capaz de hablar de dicha especificidad a través del análisis de sus componentes textuales y discursivos. El primer momento sincrónico del formalismo (Eichembaum 1970) deviene en la narratología estructuralista, entendida como un sistema de explicación analítico-estructural de la obra literaria, de sus dimensiones discursivas y formales a partir de una nomenclatura que esté en condiciones de explicar las ocurrencias lingüísticas en los diversos planos de la ficción; así, todo texto de ficción narrativa es susceptible de dicho análisis ${ }^{5}$. En correspondencia a la noción jakobsoniana de literariedad, como esencia o último reducto de lo literario, la narratología opera con la obra literaria «en sí». Esto anunció las limitaciones evidentes de la narratología que surgen de su restrictiva aplicación a la ficción ${ }^{6}$.

La terminología conceptual del análisis literario, así como la incorporación de un estudio tropológico de la literatura, creó cierta suspicacia y una serie enorme de preguntas en relación a otro tipo de textos y construcciones discursivas ${ }^{7}$. En este sentido, el mismo camino pavimentado hacia la especificidad literaria y su identificación a priori ${ }^{8}$ condujo a una crisis del criterio de literariedad como lo entendió el estructuralismo y la fenomenología, en aras de una

${ }^{5}$ Sin olvidar sus limitaciones, observadas tanto por la sociología de la literatura como por la teoría de la recepción y el posestructuralismo.

${ }^{6}$ Filósofos como Ricoeur o historiadores como White reclamaron la aplicación de la narratología al discurso histórico.

${ }^{7}$ Pienso en Van Dijk y la ampliación de su campo de estudio al discurso y la inclusión de la literatura en este ámbito como en una especie de indistinción formal, en la medida que compartiría características con el chiste, la propaganda; sus límites son más bien convencionales antes que intrínsecos a ella.

8 Cfr. Martínez Bonati (1983) [1960]. 
reflexión en torno a la referencialidad de los discursos; discusión en que la literatura cabía como la especie en relación al género. Una especie que cada vez más perdía sus límites o que se volvían más vulnerables ${ }^{9}$.

Sin duda la historia se nutrió de este debate como el convidado de piedra que ve con cierta suspicacia el surgimiento promisorio de esta ciencia literaria. ¿La literatura una ciencia? Algo poco probable: Si hace poco más de cincuenta años ambas compartían estrechamente el palco de las ciencias humanas y sociales, en donde la literatura llevaba una considerable desventaja debido a sus métodos y fines, justamente por querer acercarse a la historia —o querer hacer «otro tipo» de historia-.

Con la relectura que el siglo XX hizo de las poéticas clásicas, en particular la aristotélica, la consiguiente discusión de conceptos como mimesis o narración ${ }^{10}$, o la rearticulación de una teoría de los géneros $\mathrm{y}$, en especial, la reelaboración estructuralista de los criterios para una praxis poética a partir del desarrollo de una teckné en función de un ars como un «saber hacer» (poético, histórico, de la memoria, etc.), relevo de la noción de representación, surge - $\mathrm{O}$ resurge bajo otro panorama y con otras propuestas - un discurso crítico sobre la historia, que acusa participación en el juego de los desmontajes, significancias y subtextos, estructuras profundas y de superficie, manifiestas o latentes. Esta variación condujo a una lectura crítica de la historia entendida como ars historiae, como «artefacto» de lenguaje, tanto de mano de críticos estructuralistas —o en vías al postestructuralismo- como de historiadores y filósofos. Este ejercicio metadiscursivo, que los estudiosos de la literatura y escritores hicieron frecuente no solo con la literatura sino en la literatura y que llevó a la metaliteratura al estatuto de pauta artística, expresión de una nueva sensibilidad

9 En relación a este tema incorporo la reflexión hecha por Leonidas Morales en relación al influjo de las vanguardias en los modos de resignificar — o reposicionar — el problema del referente y con ello una crítica a los criterios restrictivos de lo literario, que pasaban de ser estéticos (Genette) en la medida que la misma estética se convirtió en blanco y descrédito a partir de la crítica a las ideologías, junto con la revolución en la concepción de la obra de arte con las vanguardias y posterior a ellas (Schopf, Bürger).

Las arremetidas contra la dimensión estética como criterio de definición y tratamiento de lo literario continuaron con ímpetu hasta, por ejemplo, los años ochenta; pienso en la derogación del término literatura colonial hecho por Rolena Adorno y su sustitución por el de discurso colonial con todos los alcances válidos que su propuesta contiene, pero con la serie de (auto)restricciones de lectura que supone desplazar sin más a la estética con las posibilidades de resignificarla y resituarla a la luz de nuevos textos y contextos culturales. Esta declaración en Adorno señala más bien un rechazo a la literatura (la literariedad) que a la estética como disciplina artística de la percepción y el juicio, surgida en el siglo XVIII.

10 Véase Schaeffer (2002). Una de las reevaluaciones más pertinentes a la discusión de la noción de mimesis, vinculada a la ficcionalidad. El autor no equipara estos procedimientos, cuestión central para la comprensión de los distintos niveles planteados por ambas categorías, como sustratos no solo ontológicos, sino discursivos y estéticos. 
o simplemente moda, fue adoptado y ensayado por los historiadores con su propia disciplina ${ }^{11}$.

La metahistoria - que no es la pólvora, en la medida que J. B. Vico se le considera un metahistoriador (Munz 1990) - instaló una perspectiva crítica - en algunos casos polémica - respecto de la figura del historiador y los modos de hacer historia como un intento por desacralizar el modelo histórico decimonónico de pretensiones científicas (o modelo nomológico), heredero directo de la historia objetivista rankeana del siglo XIX. La perspectiva discursiva, tropológica y narratológica abrió un campo de posibilidades para analizar y comprender la historia pasada o contemporánea a la luz de variantes que en algún momento fueron dadas por sentadas: el estatuto del historiador como narrador en las determinaciones de la voz (Genette); el acontecimiento versus la narración; la dimensión ontológica y fenomenológica del tiempo asociada a la configuración de la trama; el tramado (White) tropológico que es vehículo ideológico, hasta llegar a las reflexiones actuales en torno al papel de la historia en relación con la memoria (Ricoeur). Asimismo, la filosofía de la historia de pensadores como Vico, Burkhardt, Hegel, Benjamin, Michelet, es releída a partir de nuevos correlatos teóricos que configuran panoramas teórico-historiográficos inéditos ${ }^{12}$.

\section{TIEMPO, NARRACIÓN}

Detrás de cada narración hay un sujeto. Las relaciones entre tiempo y narración, como construcciones mutuamente condicionadas, soportes de toda forma discursiva y —en cuanto que son planteadas desde un punto de vista ontológico - anteriores a las relaciones entre literatura e historia, permiten desmontar las distancias entre literatura e historia construidas desde el siglo XIX como separación y especialización de saberes para replantear la ficción, no solo como suspensión de «la realidad» u operación tropológica (que es la perspectiva de White adjudicada al texto histórico) ${ }^{13}$, sino como uno de los modos fundamentales de expresión, comprensión y conocimiento, entendidos como universales poéticos.

${ }^{11}$ Véase este problema en otro ensayo de Hayden White (2011). En este punto es de importancia la idea de ficcionalización dentro del debate historiografía y retórica.

${ }^{12} \mathrm{Me}$ refiero al estructuralismo, postestructuralismo y sicoanálisis. Véase Kellner (1989).

${ }^{13}$ En torno a ambos temas se ha desarrollado una vasta discusión teórica que será incorporada más adelante. Primero, en relación con el problema del reflejo histórico en la literatura, en relación al género de la novela histórica y el paradigma realista de la representación, y la dimensión retórica del lenguaje en general, teorizada, principalmente, por Paul de Man, en que esta no es una cualidad privativa del lenguaje literario o de la ficción. 
La «narración del pasado», en este sentido, implica dar cuenta de varias dimensiones, enfoques y salvedades. Por un lado, el hecho de plantear el problema ontológico acerca de la posibilidad de emitir juicios respecto de ese pasado, esto es, la posibilidad de dicha narración sobre el pasado, con las consiguientes implicancias en la enunciación y la referencia ${ }^{14}$, sumado al estatuto que ocupa la representación, la cual nos lleva al problema de la experiencia, en general, así como a la experiencia de dicho pasado, en particular ${ }^{15}$. Por otro lado, la reflexión en torno al pasado conduce necesariamente a una mirada fenomenológica en torno al tiempo: es imposible pensar en un pasado desprovisto de sus vínculos con el presente que lo articula y enuncia, siempre fugaz, junto con las potencialidades que dentro de él están contenidas ${ }^{16}$ como realización futura $\mathrm{y}$, con ello, la capacidad de tener experiencia de él. Pero, ¿cómo tenemos experiencia del tiempo? ${ }^{17}$ Por cierto, nadie pone en duda la certeza de tenerla; por medio del lenguaje, en el lenguaje. De la aporía del lenguaje, Ricoeur opta por el análisis de los relatos ${ }^{18}$ históricos y de ficción, que tienen como referente común el carácter temporal de la experiencia, «de este modo, la narración se eleva a condición identificadora de la existencia temporal»y, a su vez, «el tiempo es una cavilación inconclusiva a la que sólo responde la actividad narrativa» (Ricoeur 1998-1999: 43), instalando la narración como el modus de experiencia (y expresión) del tiempo por parte del individuo. El hombre realiza su subjetividad a través de la exteriorización de la narración; entra en contacto con el mundo, ordena los eventos, los dispone, los

${ }^{14}$ Estas preguntas son hechas desde una perspectiva del discurso, según Benveniste, Peirce y los aportes de la lingüística formalista y estructural (Jakobson).

15 Trasladar el problema del pasado y la narración a la experiencia, indica más que un cambio de rumbo en la fenomenología, un anclaje hermenéutico en las ideas que Ricoeur representa, como trabajo con los textos de la cultura, entendiendo el sentido como búsqueda. No creo que hablar de la experiencia en relación al tiempo y la narración sea un acercamiento forzado, muy por el contrario. Incluso para el mismo Paul Ricoeur sus reflexiones, en La memoria, la historia y el olvido, decantan en una hermenéutica de la experiencia y sostienen un interesante diálogo con las reflexiones que Walter Benjamin hace en torno al tiempo pasado, la historia y la experiencia que se articulan en el tiempo — la utopía, la alegoría - de la redención.

${ }^{16}$ Los relatos construidos hacia el futuro o en el futuro tienen una condición de expectativa que los caracteriza. Sin embargo, no formulan un juicio más verosímil que la narración sobre el pasado, incluso, desde el punto de vista de los speech acts, muchas veces son precisamente ellos la garantía de sí mismos y se sostienen en retóricas o constructos culturales más amplios. Pienso en las profecías, la ciencia ficción — que es un caso de gran interés-y los discursos políticos.

17 Ya que resulta imposible definirlo, como dirá San Agustín: «¿Qué es, entonces, el tiempo? Si nadie me lo pregunta, lo sé; si quiero explicárselo a quien me lo pregunta, ya no lo sé» (citado de Ricoeur 1998-1999: a34).

18 Yendo más allá del Dasein heideggeriano. 
construye, da sentido ${ }^{19}$. La identidad del yo simbolizado se despliega en la narración, constituyendo una «identidad narrativa» o «identidad narrada» (ibíd.: a12 T1).

La narración ocurre gracias a una operación mediadora, común a la narración histórica y a la ficticia: la trama, capaz de conferir unidad e inteligibilidad «por medio de la síntesis de lo heterogéneo»: «Veo en las tramas que inventamos el medio privilegiado por el que re-configuramos nuestra experiencia temporal confusa, informe y, en el límite, muda» (ibíd.: a34 T1). La trama materializa el tiempo, lo dota de representación, da lugar al acontecimiento, como evento integrado a una historia, capaz de significar en su relación con otros acontecimientos.

Vemos que narración, tiempo y trama están imbricados en un proceso único, para Ricoeur. Sin embargo, la trama constituye otro nivel junto con la $m i$ mesis (aristotélica), aunque no menos significativo.

Si tiempo y narración son entendidos como condiciones de la existencia, siendo, para estos efectos, la narración instalada epistemológicamente ${ }^{20}$ por Ricoeur, trama y mimesis corresponden a operaciones o procedimientos (teck$n e ́)$ inherentes a los modos de expresión de la experiencia temporal viva y a la construcción de sentidos a través del relato. Trama y mimesis aristotélica son revisadas y resignificadas por Ricoeur en relación al concepto de mythos y la consiguiente división de la mimesis en tres etapas, siendo de interés para el presente escrito mimesis $\mathrm{II}^{21}$.

El mythos aristotélico significa «componer». «Es la disposición de los hechos en sistema» (Ricoeur 1999-1999: 83aT1), es en este sentido que mythos corresponde a trama. Ricoeur rescata de Aristóteles que lo esencial es que el poeta sea «compositor de tramas» (88), con lo cual identifica trama con mythos y mythos con narración (y por contigüidad, con la dispositio aristotélica). Sir-

19 Este argumento también es parte de las teorías en torno a los géneros literarios como los modos fundamentales de relación del hombre consigo mismo y el mundo (cfr. Staiger 1966).

20 Podríamos precisar: «construida» epistemológicamente, como modo de existencia del hombre y la mujer en el mundo. En este sentido, resulta notable la propuesta teórico-filosófica de Ricoeur, pues —en un ejercicio metafórico- construye a la narración como locus (de la enunciación y del enunciado). Esto trae implícita la relación tiempo-espacio, al dar cuenta de la especialidad como posibilidad del tiempo (ver San Agustín en Ricoeur 19981999) y de la narración como «referencia metafórica» del tiempo-espacio, en la medida que hablamos del «poder que tiene el enunciado metafórico de redescribir una realidad inaccesible a la descripción directa» (ibíd.: 33aT1).

21 Paul Ricoeur establece tres niveles en la mimesis, que dan cuenta de su dinamismo: mimesis I, referente al «antes» de la composición poética, mimesis II o mimesis-creación, que es donde se concentra esta exposición, y mimesis III que se ocupa del «después» o recepción de la obra. 
viéndose de la argumentación aristotélica, para Ricoeur la narración será requisito tanto de la epopeya como de la tragedia ${ }^{22}$.

Esta comprensión y función del mythos no es posible sin la mimesis, entendida como «actividad mimética», que no es ni calco de la realidad preexistente ni redoblamiento degradado de la esencia, sino imitación creadora y representación como «corte que abre el espacio de ficción» (Ricoeur 1998-1999: 103aT1). De manera más precisa, «la mimesis no tiene sólo una función de corte, sino de unión, que establece precisamente el estatuto de trasposición "metafórica" del campo práctico por el mythos» (ibíd.), yendo de la ética a la poética.

Ricoeur traslada el énfasis del modo aristotélico de la narración (directo o indirecto) al objeto, «ya que llamamos narración exactamente a lo que Aristóteles llama mythos, la disposición de los hechos» (88). Pero luego establece una nueva distinción entre la narración en sentido amplio, como mythos o el «que» de la actividad mimética versus la narración que corresponde a la diégesis aristotélica y que Ricoeur llamará composición diegética (88). Surge, así, una nueva distinción de planos entre mythos y esta última al interior de la narración.

La trama formaliza ${ }^{23}$. Responde a los criterios de probabilidad y necesidad aristotélicos, por tanto, su vínculo interno es más lógico que cronológico. Este hecho confiere un estatuto autónomo a la «práctica poética» (94), relacionada con una «inteligencia» mimética y mítica: «Aprender, deducir, reconocer la forma: éste es el esqueleto inteligible del placer de la imitación (o de la representación)» (ibíd.) $)^{24}$.

\section{II.1. UNIVERSALES POÉTICOS}

La poesía y la historia corresponden al primer binomio de universales poéticos ${ }^{25}$, en la medida que encarnan la doble oposición: de lo posible a lo efectivo y de lo general a lo particular.

${ }^{22}$ Se trata de una teoría de la narración contenida en la teoría sobre la tragedia $-\mathrm{y}$ la tragicidad- aristotélica. Propondrá Ricoeur una narratividad implicada en el modelo trágico por la trama y en que lo dramático es un modo de configuración al interior de la trama: «Las tramas deben estructurarse de manera dramática» (Aristóteles 1974).

${ }^{23}$ Esta idea me parece central en relación a la poética y la forma en la discusión en torno a la obra de arte. Esta afirmación la hago a partir de las reflexiones de Kermode (1983) a propósito de la trama.

${ }^{24}$ En Verdenius (1981) puede encontrarse el sustrato protofilosófico de las proposiciones de Ricoeur sobre el sentido de imitación como modulación del mythos; cuando queda sugerido que la imitación es «aproximación» y que, en lugar de la idea de copia, es de mayor pertinencia la de trasposición.

25 O filosóficos, según Ricoeur. 
Lo posible y lo general no se realizan sino en la disposición de los hechos. La trama - como mythos - es vehículo y objeto de manifestación de los universales (poéticos). A la trama y su existencia efectiva está íntimamente ligado el criterio de verosimilitud (o necesidad). «Es la trama la que debe ser típica» (95) dirá Ricoeur, tras lo cual se desprende que, por un lado, la verosimilitud es cultural y que, por otro, dependerá de la transmisión de mitos (o historias) que son un «manantial» de pasiones y que posibilitan la configuración poética. Sin mito no habría poesía, pero el hombre y la mujer no pueden existir ni comprenderse despojados de sus pasiones ${ }^{26}$. Aquí se produce la primera relación dialéctica de la que surgen los universales.

La trama genera los universales gracias al principio de ordenación, mientras que la mimesis potencia del mythos, no su carácter de fábula, sino el de coherencia. Ordenación y coherencia se transforman en requisito de los universales, los cuales no corresponden a ideas platónicas, son, por el contrario, «universales próximos a la sabiduría práctica» (Ricoeur 1998-1999: 96) ${ }^{27}$. «Componer la trama es hacer surgir lo inteligible de lo accidental, lo universal de lo singular, lo necesario o lo verosímil de lo episódico» $(96)^{28}$.

La mimesis posee, por su parte también un hacer universalizante expresado, para Ricoeur, en el «comprender» narrativo ${ }^{29}$.

No corresponde al poeta decir lo que ha sucedido, sino lo que podría suceder, esto es, lo posible según verosimilitud o necesidad. En efecto, el historiador y el poeta no se diferencian por decir las cosas en verso o en prosa [...]; la diferencia está en que uno dice lo que ha sucedido, y el otro, lo que podría suceder (Aristóteles 1974: 158).

Por medio de lo verosímil el poeta «distingue sus tramas de las historias recibidas» (ibíd.: 107), sean estas sucedidas realmente o solo existentes en la tradición (poética), sin descartar en lo verosímil un fin persuasivo más allá de la pura «lógica poética». En este comentario advertimos que el poeta trabaja con un material dado, preexistente, en que la dimensión creadora — más que

${ }^{26}$ En este punto es importante hacer una indicación: Paul Ricoeur no hablará de pasiones, como la materia contenida por el mito, sino de «violencia». He optado por utilizar el término pasiones para sugerir estados más amplios que, desde mi punto de vista, corresponderían a la antesala de lo que Aristóteles entiende por acciones y que sería plausible comprender como «pasiones formalizadas» al interior de su sistema.

${ }^{27}$ Vinculados a la ética y la política, inclusive.

${ }^{28}$ Para Ricoeur también el cambio, o peripecia, y la agnición son universales esenciales a cualquier historia, más allá de la forma trágica: «¿No intentan también los historiadores poner lucidez donde hay perplejidad? Y ¿no es mayor la perplejidad donde los cambios de fortuna son más inesperados?» (Ricoeur 1998-1999: 101aT1).

${ }^{29}$ Ricoeur utiliza el término neokantiano verstehen, que designa el modo de conocimiento de las ciencias del Espíritu (no causales, no deterministas). 
creativa $^{30}$ - proviene de la operación de la trama, esto es, del trabajo (de orden y coherencia) que sobre dichos materiales de la tradición o del pasado el poeta realiza. Aristóteles (1974: 136) puntualiza: «si uno no ha visto antes al retratado, no producirá placer como imitación, sino por la ejecución, o por el color o por alguna cosa semejante».

El terreno de lo que «podría suceder», en relación al ámbito de libertad y dominio del poeta, tiene que ver con dicha probabilidad en función de la tradición y el mythos que se extrae de ella. «Por eso también la poesía es más filosófica y elevada que la historia; pues la poesía dice más bien lo general, y la historia, lo particular» (ibíd.: 158).

La poesía se refiere a un tipo de hombres, la historia, a hombres particulares. La poesía puede prescindir de los nombres, o incluso ponerlos al final, como resultado de la composición de fábulas ${ }^{31}$. Sin embargo, la composición poética muchas veces requerirá de la credibilidad como refuerzo a la verosimilitud —en el caso de la tragedia - y echa mano a la tradición mitográfica, «donde los personajes tenían ya sus nombres e incluso aparecían caracterizados de algún modo» (García Yebra en Aristóteles 1974: 274). Pero lo central en torno al acervo poético será «no [...] alterar las fábulas tradicionales», sino que el poeta debe inventar por sí mismo y «hacer buen uso de las recibidas» (Aristóteles 1974: 175-176), creándose una identificación entre el poeta y las fábulas que compone.

En términos compositivos, Aristóteles realiza una distinción entre epopeya e historia ${ }^{32}$. Si bien en la epopeya las fábulas pueden ser muchas, a diferencia de la tragedia, estas deben estructurarse en torno a una sola acción, esto es, debe tener unidad de acción, especificando, «no deben ser semejantes a los relatos históricos, en los que necesariamente se describe no una sola acción, sino un solo tiempo, es decir, todas las cosas que durante él acontecieron a uno o a varios, cada una de las cuales tiene con las demás relación puramente casual» (Aristóteles 1974: 215). El telos, o fin, confiere unidad a la acción; pueden ocurrir eventos simultáneamente, en tiempos contiguos, pero no guardan una relación de unidad (de acción), pues no comparten el fin.

No habría que pasar por alto el hecho de que Aristóteles advierta la confusión de la unidad de acción con la de tiempo como uno de los errores más frecuentes en los poetas, ya que para efectos de mi exposición significa una confusión entre la composición y los modos de referencia de la poesía y la

\footnotetext{
${ }^{30}$ Recordando que la creatividad y la originalidad en el arte son concepciones románticas.

31 Por ejemplo, la poesía lírica o la comedia, en que los nombres son ficticios.

${ }^{32}$ Este hecho implica una semejanza entre determinada especie poética - la epopeyay la historia. Lo cual no ocurre compositivamente con la tragedia, sino con la referencia, en general, de la poesía.
} 
historia, lo cual denuncia la inestabilidad de sus límites ${ }^{33}$. No hay que dejar de señalar el carácter preceptista, sistemático y analítico de Aristóteles capaz de, teóricamente, delimitar los ámbitos de la poesía y la historia, en tanto expresiones de universales poéticos o filosóficos. Poéticos, en la medida que cada cual da lugar a una teckné, que no radica en el uso distintivo de prosa o verso, sino en el modo de configurar y representar la realidad: lo general y lo particular, acción y tiempo. En definitiva, poesía e historia generan y transmiten conocimientos particulares en la perspectiva de Aristóteles y es, en este sentido, que hablamos de universales filosóficos, definidos por construir sus relatos en vista de lo posible y lo efectivo, respectivamente.

La perspectiva de Paul Ricoeur aboga por un universal anterior a la distinción poesía e historia. La narración es universal de la experiencia del tiempo como condición humana. Esta perspectiva supone comprender que el lenguaje siempre está dado en un tiempo, con lo cual la narración se transforma en una locación, un locus configurador de sentido a través de la trama - como mythos-, común para la poesía y la historia.

\section{II.2. RELATO DE FICCIÓN VERSUS RELATO HISTÓRICO}

\section{II.2.1. El problema de la narración}

Podríamos señalar que uno de los factores que ha definido a la historia moderna es su cualidad narrativa. La historia moderna es narrativa: el siglo XIX es un siglo narrativo ${ }^{34}$. Durante los siglos VI y XVI la historia no se diferenciaba de la crónica y los anales; todos daban cuenta de hechos que en la realidad habían acontecido. El siglo XVI marca un punto de inflexión en este panorama en cuanto la historia se diferencia del resto de los géneros por su orientación investigativa y su avance en la conciencia y la narración históricas. La crónica queda en el estadio de mero registro de datos sin principio, medio ni fin, «no describe sino un segmento de tiempo» (Lozano 1987: 46) insuficiente para la inteligibilidad del pasado. Por el contrario, el relato histórico realiza una «intervención» en la segmentación temporal: comenzar por el principio e ir hasta el final de una «narración continua», que constituye una totali-

33 Dialogando con los términos aristotélicos, no sería errado colegir que la historia está igualmente sujeta a mimesis, en la medida que utiliza el mecanismo de la trama y «representa» lo efectivamente acontecido. Este tipo de argumentos son los que dan curso a las propuestas de White en torno al «texto histórico como artefacto literario», que discutiré más adelante.

${ }^{34}$ Son importantes las argumentaciones sobre narración y representación en el contexto del pensamiento histórico - como pensar de la historia - en el siglo XIX en las investigaciones de J. Mali (2003) y H. Kellner (1989). 
dad textual coherente, por tanto, significativa. White hablará de motivos inaugurales, de transición y de terminación (Lozano 1987: 47). «La crónica de los acontecimientos, entonces, ha sido transformada en un proceso diacrónico completo sobre el que se pueden hacer preguntas como si se tratara de una "estructura sincrónica" de relaciones» (ibíd.: 48).

La anterior definición será central para distinguir dos acepciones del término historia, pero que son finalmente tres: la investigación de lo ocurrido y el conocimiento (histórico) que de ello se obtiene; la narración y exposición de los acontecimientos pasados (historiam rerum gestarum), o sea, su relato; y por último, lo que realmente ha sucedido (res gestae). La historiografía vendrá a ocupar tanto el lugar de la segunda acepción, como de la primera.

La historia, definida como una narración de acontecimientos, ha sido el punto de vista tradicional de la disciplina, solventado por el argumento de que la narración es una forma de razón (Ortega y Gasset en Lozano 1987: 114), así, la razón histórica consiste en narrar, «contar un cuento bien verídico». «Los hechos y acontecimientos existen en cuanto que pertenecen a una narración» o «será en la narración donde habrá que descubrir los hechos y acontecimientos» (Lozano 1987: 114).

Sin embargo, el modelo narrativista ha tenido críticas a través tanto del rechazo al concepto de acontecimiento en la escuela historiográfica francesa, como en la elevación del mismo a estatuto científico, en el caso de la epistemología de la historia del positivismo lógico (modelo nomológico).

Comúnmente, en la noción de acontecimiento operan tres supuestos: el haber-sido absoluto de este, el ser adjudicado a una acción humana absolutamente pasada y ser comprendido como una alteridad absoluta susceptible de explicación (Ricoeur 1998-1999: 171 TI). La historiografía francesa plantea el problema de los límites de la objetividad histórica a través de la «disolución del objeto» (ibíd.: 172), esto es, «en la medida en que el historiador está implicado en la comprensión y en la explicación de los acontecimientos pasados, un acontecimiento absoluto no puede atestiguarse por el discurso histórico» (ibíd.). La comprensión no es una intuición directa, sino una reconstrucción. Con esta perspectiva, Raymond Aron - a quien hace referencia Ricouer - estaría discutiendo el modo de hacer historia en razón a formas venideras más adecuadas y críticas en relación a los paradigmas anteriores: «La apuesta filosófica era, para Aron, la destrucción de cualquier ilusión retrospectiva de fatalidad y la apertura de la teoría de la historia a la espontaneidad de la acción orientada hacia el futuro» (ibíd.: 173). El veredicto es radical: «El pasado, concebido como el conjunto de lo que realmente ha sucedido, está fuera del alcance del historiador» (ibíd.). El punto central de esta perspectiva crítica es la incorporación de la figura del historiador como sujeto configurante del discurso histórico, esto conlleva un replanteamiento de las fuentes y del conocimiento del pasado que, eventualmente, la historia estaría facultada para entre- 
gar $^{35}$, considerando que «el conjunto de los procedimientos de la historia forma parte de la ecuación del conocimiento histórico» (ibíd.: 175). La disolución del objeto, aludida anteriormente, trae como consecuencia una nueva relación con el pasado, un pasado accesible, pero que no es objeto de conocimiento, pues cuando era presente, dicho pasado no distaba de ser como el nuestro: «Confuso, multiforme, ininteligible» (ibíd.: 174) ${ }^{36}$. Estas posiciones, indirectamente, sancionan a la narración — asociada a la filosofía de la historia - como modelo explicativo pero, a su vez, acercan al historiador al estatuto del narrador.

\section{II.2.2. El problema de la ficción}

Las teorías narrativistas en la historia conducen inevitablemente al problema de la ficción por razones compositivas y referenciales, que afectan a las configuraciones del tiempo y a la pretensión de verdad, respectivamente. En la literatura las teorías narrativas alcanzan un grado de autoridad y autonomía, resultado del análisis aplicado a los textos de ficción, entendidos como estructuras cuyos sentidos profundos son develados a través de dichos procedimientos. Los límites entre lo literario y lo no literario son cada vez más inciertos cuando la ficción y la imaginación son consideradas parte constituyente de la memoria y de las formas de elaborar relatos por las comunidades como registro de la experiencia del pasado. Por este motivo, la ficción no se instala como sinónimo de literatura ni como oposición a Historia o Verdad. La historiografía ha hablado de procesos de ficcionalización en la historia (Ricoeur 1998-1999: 176) y la literatura, como bien sabemos, ha pretendido ser historicista o veraz. Las teorías históricas hablan de una imaginación histórica o a priori (Collingwood 1965; Ricoeur 1998-1999), funcionando en la configuración del discurso histórico, mientras que la literatura comienza a identificarse por las convenciones asociadas a lo literario, más que por cualidades — intrínsecamente- estéticas.

La ficción es, precisamente, la piedra angular en la relación y diferenciación entre literatura e historia. Por este motivo creo necesario considerar las metamorfosis de la ficción y ubicar sus sustratos. El concepto contemporáneo de ficción, con el que se ha designado a las composiciones literarias, no tiene

35 Ideas como el complemento entre subjetividad (comprensión) y objetividad (explicación), la crítica al testimonio y la imposibilidad de re-actualizar el pasado por parte del historiador al estar implicado en dicho conocimiento, son algunas de las críticas de la escuela historiográfica francesa al paradigma histórico tradicional.

${ }^{36}$ A la idea de acontecimiento (tiempo breve) se opone la de «larga-duración». Este paso está dado por el tránsito de la historia política a la historia social, el tiempo de larga duración es la forma de desarrollo de las instituciones políticas y de las mentalidades (Ricoeur 1998-1999: 182). La escuela francesa también hará una crítica al modelo explicativo (estilo Collingwood) y al modelo científico (nomológico) que hace primar el acontecimiento. 
existencia en la Poética de Aristóteles, como tal. La contraposición real/ficticio no configura universales, tampoco es la contraparte a la distinción entre lo efectivo y lo posible, en su correlación con lo particular y lo general, categorías que sí configuran universales. Sin embargo, en la Poética, Aristóteles alude a la presencia de lo maravilloso en la composición poética. Provocado por lo irracional, lo maravilloso es más oportuno en la epopeya que en la tragedia, «porque no se ve al que actúa» (Aristóteles 1974: 222) gracias al artificio del lenguaje poético en la narración ${ }^{37}$. «Y lo maravilloso es agradable; y prueba de ello es que todos, al contar algo, añaden por su cuenta, pensando agradar» (ibíd.). Entonces, si bien lo maravilloso es permitido - - deseado- en la composición narrativa, no es su condición ni definición; no constituye universal. Mythos sigue operando como ars compositivo sobre la tradición ${ }^{38}$. En la preceptiva retórica lo que identificamos como ficción tiene que ver con el elemento maravilloso en el argumento y con la invención (inventio) de la trama, pero nunca lleva a producir una división en clases de discursos ${ }^{39}$, sino hasta el siglo XVIII con las poéticas y estéticas prerrománticas. Desde ellas arranca el argumento que identifica la ficción con la dimensión estética de las obras literarias como percepción y experiencia de la belleza. Sin embargo, las teorías estéticas y literarias de fines del siglo XIX y principios del veinte han advertido la complejidad y el nuevo terreno, tanto de la ficción como de la estética ${ }^{40}$.

Esta postura es renovada por Gerard Genette al indicar que los textos de ficción (u obras literarias) se caracterizan por su función estética. Redefinir la estética o mantener el argumento estético después de las vanguardias artísticas no es una tarea fácil, sobre todo si se recurre a ella para centrar un objeto múltiple (las formas de la ficción), que es comprendido desde su cualidad narrativa. El pannarrativismo es uno de los resultados de la narratología que, si bien ha surgido desde el análisis del texto literario, es susceptible de ser aplicada a todo texto narrativo, pues la narración no es sinónimo de ficción ${ }^{41}$. En este contexto, la historia reclama su ingreso al análisis estructural ${ }^{42}$.

37 Pues sería ridículo poner lo maravilloso o irracional en escena, según Aristóteles.

38 Este argumento lo retomo de Ricoeur.

39 En la Retórica de la España del Siglo de Oro, la inventio correspondía al «procedimiento para encontrar los argumentos que explicarían la cuestión», argumentos que podían provenir de la realidad verdadera «o imaginada como verdadera» y del cúmulo de saberes del orador (notas, fuentes eruditas) (López Griega 1994: 21). Sin olvidar la interpretación (equivocada) que el Renacimiento hizo de la verosimilitud aristotélica, entendiéndola como «verdad», base para el desarrollo de la concepción realista del arte.

40 Véase Croce (1967) [1912]. Los textos de Marinetti son fundamentales para esta discusión (De Micheli 1999 [1979]).

${ }^{41} \mathrm{Y}$ a su vez ficción no es sinónimo de narración, argumento de base a la teoría de los géneros.

42 «Hablando con rigor, se debería llamar narratología a la ciencia de las estructuras narrativas, sin tener en cuenta la distinción entre narración histórica y relato de ficción. Sin 
El problema es resuelto por Genette oponiendo ficción a dicción; el criterio temático versus el criterio formal o remático, respectivamente. Pero son varios los postulados que hacen restrictivos a la ficción elementos comunes a otros discursos. Un ejemplo de ello es la traducción de mimesis por ficción ${ }^{43}$. En Ricoeur hemos visto que esta distinción es clave al momento de diferenciar el relato histórico del relato de ficción: en la historia habría mimesis, en la medida que se articula una trama. Otro tanto ocurre cuando Genette entiende que la capacidad poética del lenguaje estriba, para Aristóteles, en crear y disponer una historia, pero vemos que también es una cualidad compartida con la historia. Por otro lado, si la ficción ${ }^{44}$ se caracteriza por su ruptura con el régimen ordinario del lenguaje ${ }^{45}$ a través de los «enunciados de realidad» (reality statement), esto es:

Authentic speech acts accomplished with respect to reality by a real and determinated "I-Origo". In fiction, we encounter not utterances of reality but fictional utterances whose true "I-Origo" is not the author or the narrator but the ficticious characters, whose viewpoint and spatiotemporal situation control the entire enunciation of the narrative, down to the grammatical details of its sentences (Genette 1993: 12).

Vale la pena recordar la definición dada por Ricoeur de la frase narrativa de Danto, destacando los tres «aspectos temporales» que se encuentran implicados en la frase narrativa: «El del acontecimiento descrito, el del aconteci-

embargo, según el uso actual del término, la narratología se concentra en el relato de fícción, sin excluir algunas incursiones en el campo de la historiografía» (Ricoeur 2008: 379).

${ }^{43}$ «It is thus as though Aristotle had set up a distinction between two functions of language: its ordinary function, wich is to speak (legein) in order to inform, interrogate, persuade, order, promise, and so forth, and its artistic function, wich is to produce works (poiein). The first function belongs to rhetoric (today we would be inclined to say pragmatics), the second to poetics. But how can language, wich is ordinarily an instrument of communications and action, become a means of creation? Aristotle's response is clear: there can be no creation by way of language unless language becomes a vehicle of mimesis, that is, of representation, or rather of the simulation of imaginary actions and events; unless language serves to invent stories, or at least to transmit stories that have already been invented» (Genette 1993: 7). Aquí mimesis adquiere el sentido amplio de representación o simulación de acciones imaginarias, lo cual la emparenta con la ficción. Este segundo sentido no está presente en Ricoeur directamente, ya que se cuida de situar la trama o mythos no como simulación, sino como composición narrativa. La ficción, entonces, resultará de las modulaciones del tiempo en la narración, en este sentido, la ficción es una entidad imaginaria capaz de configurar temporalidades específicas y diversas (tiempo fenomenológico versus tiempo cosmológico u ordinario [Ricoeur 1998-1999]).

${ }^{44}$ Entendida según el duopolio del que habla Genette, siguiendo a Käte Hamburger, del género ficcional o mimético (narrativa y drama) y del género lírico (Genette 1993: 12).

${ }^{45}$ Esta distinción entre lengua poética y lengua coloquial proviene del primer período formalista (Véase Eichembaum 1970). 
miento en función del cual se describe el primero y el del narrador, los dos primeros concernientes al enunciado y el tercero a la enunciación» (Ricoeur 1998-1999: 246), definición que se nutre directamente de los estudios de Gerard Genette en torno al relato, la narración y la ficción. El punto de discusión se genera en la figura que transmite el mensaje y su relación con la verdad y la realidad, en que la dicción es compartida por ambos discursos: «The same resources are used, but differently coordinated and differently stimulated, in a system of acts that hencefoth have their end in themselves» (Genette 1993: 13).

Genette, como escape a los esencialismos, propondrá un enfoque «condicionalista», que sustituye la pregunta «¿qué es la literatura?» por «¿cuándo y dónde se da la literatura?». Considerando que todo trabajo verbal de la ficción es, inevitablemente, considerado como literario, cuya «aesthetic attitude» (Genette 1989: viii) corresponde al «disinterest with respect to the real world» (ibíd.), tanto la novela histórica como la filosofía de la historia ponen en duda este juicio de raíz kantiana ${ }^{46}$. Pero, volviendo a la pregunta que Genette reformula, y considerando que la dicción opera como base a los «trabajos» del lenguaje: «Nonfictional prose, can be perceived as literary only in a condicional fashion, that is, by virtue of an individual attitude, such as Stendhal's view of the style in wich the French Civil Code was written» (Genette 1989: viii). Podemos discutir que se trata de algo más que de una actitud individual o que dicha actitud, en algunos casos, elabora un sistema tan amplio y complejo como en el caso de la novela histórica realista o la novela latinoamericana del boom, del realismo mágico, del mito o de la historia. A menos que nuestro juego irónico se sostenga en suculentas bases, no podríamos considerar la guía telefónica una obra literaria, sin que el juego dadaísta se dé por entendido.

Mientras que para Genette la dimensión literaria se distingue por una «actitud individual» — que no es sino una «actitud estética»—, para Danto la narración histórica se vuelve significativa o distintiva fuera de la historia en relación con otros textos y disciplinas ${ }^{47}$, como salida a la indistinción discursiva, en que la narración ubica a la historia frente a la ficción, tras la lectura narratológica aplicada a la historiografía.

Genette advierte que las distinciones entre discursos ficcionales y factuales no son posibles de establecer de un modo tajante luego de revisar su teoría del discurso del relato. No se trataría, simplemente, de llamar ficcional a una literatura por el carácter imaginario de sus objetos y diccional o factual a aquella que destaca sus características formales. La forma es determinante para los

\footnotetext{
${ }^{46}$ Las teorías de la fícción y de los mundos posibles han demostrado que no es plausible solo pensar en una suspensión de los criterios lógicos de verdad/falsedad cuando hablamos de literatura.

47 Esta perspectiva oposicional o diferencial no es nueva para los estudios literarios debido a la influencia lingüística. Formulaciones similares han sido hechas por Van Dijk (1998) y Eagleton (2007) [1983].
} 
modos imaginativos que, convencionalmente, concebimos no ficcionales o factuales, como ocurre con la historia. Del mismo modo, en la ficción se exacerba la forma y esta, en muchos casos, se convierte en vehículo determinante de los contenidos imaginarios. «La forma es el sentido».

En la revisión de su teoría, Genette accede a aplicar la batería conceptual narratológica a textos no literarios ${ }^{48}$. De esto saca en limpio que las categorías de modo, voz y velocidad le permiten establecer algunas distinciones entre textos de ficción y textos factuales en relación a la focalización y los niveles de la narración (identificación o diferencia entre autor y narrador) ${ }^{49}$. Estas distinciones, resultado del análisis de los componentes textuales, si bien no zanjan la especificidad de unos y otros textos, promueven otro tipo de reflexiones entre literatura e historia, originadas por el replanteamiento de la ficción. Estos textos (ficcionales y factuales) se comportarían de forma distinta por motivos más complejos que la «verdad o falsedad de la historia», que postula Genette, comenzando por devolver a la ficción una legitimidad capaz de sacarla del terreno de lo falso y lo parasitario ${ }^{50}$.

Curiosamente, algunas de las teorías contemporáneas de interés sobre la ficción han provenido de la historiografía; quizás debido al impulso estructuralista y las posteriores señas deconstruccionistas, las cuales han orientado la lectura de la historia hacia los sustratos pre-decimonónicos y pre-ilustrados, incorporando tradiciones conceptuales que habían sido sometidas a olvido o borramiento por la historiografía cientificista, como la tradición literaria o retórica y la filosófica ${ }^{51}$.

Las proposiciones de Hayden White llaman la atención en los años setenta porque, directa y radicalmente, ubican a la historia al interior de una tradición literaria ficcional, cuyo estado de crisis y debilitamiento en el siglo XX se

48 "As if what was observed in that domain [narratology] could be automatically applied or transposed to nonfictional narrative forms such as history, autobiography, documentary, or the personal diary» (Genette 1993: ix).

49 El modo se refiere al acceso — más o menos directo - a la subjetividad de los personajes. Común resulta identificar la subjetividad con la ficción y de eso se ocupa la focalización: el estilo indirecto libre o el relato objetivo son los extremos — pasando por la focalización cero- típicamente ficcionales, pues el relato factual «does not rule out psychological explanation a priori, but it has to justify every such explanation by an indication of its source [...], or else it has to attenuate and indeed modalize the explanation with a cautions note of uncertanty or supposition» (Genette 1993: 66-67).

${ }^{50}$ Aludo a Searle, particularmente (Genette 1993). Pero también al punto de vista de Ricoeur acerca del lugar de la ficción frente a la historia: «evitamos la trampa de confinar la ficción a la exploración de la conciencia interna del tiempo, como si la función de la ficción, respecto al antagonismo entre las perspectivas rivales sobre el tiempo, se limitase a un simple movimiento de retirada fuera del campo del conflicto» (Ricoeur 2008: 819).

51 Véase Kellner (1989) y, sobre todo, Mali (2003). El autor pesquisa los sustratos simbólicos y míticos en Michelet, Burckhardt, Vico y Benjamin. 
explica por haber «perdido de vista sus orígenes en la imaginación literaria» (White 2003: 139). La reticencia viene no solo de la historia, sino también de la literatura, al no considerar a la historia «ficciones verbales cuyos contenidos son tanto inventados como encontrados y cuyas formas tienen más en común con sus homólogas en la literatura que con las de las ciencias» (White 2003: 109). La obra histórica es «una estructura verbal en forma de discurso en prosa narrativa» (White 1992: 9), que considera dimensiones epistemológicas, estéticas y morales, cuyo componente central es el tramado o «codificación de los hechos contenidos en las crónicas como componentes de tipos específicos de estructura de trama» (White 2003: 112), que utiliza técnicas que no difieren de las que normalmente hallamos en las novelas (supresión, subordinación, énfasis, caracterización, repetición, variación de tono, punto de vista) (ibíd.: 113). Las ideas más provocativas de su teoría radican en que la elección de estrategias conceptuales (modelos explicativos: novelesco, cómico, trágico o irónico) realizada por el historiador es ya un «acto esencialmente poético», que responde a prefiguraciones discursivas de tipo metafórico, metonímico, sinecdóquico e irónico ${ }^{52}$. En este sentido, el campo histórico estaría contenido en el lenguaje poético.

Estas declaraciones traen algunas consecuencias de interés: primero, que estas «formalizaciones de intuiciones poéticas» (White 1992: 11), que analíticamente preceden a los modos de la historiografía y la filosofía de la historia, son sancionados por las teorías particulares «para dar a los relatos históricos el aspecto de una explicación» (ibíd.), lo cual conduce, en segundo lugar, a que ningún modo está por sobre otro, con lo cual el criterio realista queda totalmente desacreditado ${ }^{53} \mathrm{y}$, junto a él, las pretensiones científicas. Por lo tanto - en tercer lugar - el criterio para elegir una perspectiva de la historia antes que otra «es por último estética o moral, antes que epistemológica» (ibíd.).

La teoría de White presenta su carácter ambiguo cuando intenta definir la ficción, que sería común tanto a la literatura como a la historia ${ }^{54}$. El argumen-

${ }^{52}$ En Metahistoria, White elabora una teoría formal de la obra histórica para analizar e interpretar «la estructura profunda de la imaginación histórica» (White 1992: 9). La naturaleza poética (modo tropológico dominante) y lingüística de la historia funciona como paradigma precrítico de una interpretación histórica, esto es, como paradigma metahistórico.

${ }_{53}$ Este comentario tiene su correlato en Ricoeur cuando en La memoria, la historia, el olvido considera el cambio de paradigma histórico que significó la microhistoria en cuanto a las «variaciones de escala» que no ubican a una por sobre la otra, puesto que «en cada escala se ven cosas que no se ven en otra escala y que cada visión es legítima» (Ricoeur 2008: 284).

${ }^{54}$ Uno de los problemas más visibles de la teoría de White (Metahistoria, «El texto histórico como artefacto literario») radica en sostener el argumento de la ficción, en gran parte, en las ideas de Northrop Frye que, si bien incorpora al mito como un estadio inicial o previo a la ficción, le da las características del arquetipo. Lamentablemente, las formulaciones de Frye elaboran un sistema cerrado - aunque podamos estar de acuerdo con algunas 
to en torno a la ficción es circular: el elemento ficcional es la estructura de trama mítica, pues detrás de cada relato hay alojado un mito ${ }^{55}$. Pero dirá White que será necesario tener conocimiento de los atributos del género para reconocer los modelos explicativos y, a su vez, reconocer el mito. De aquí se desprenden dos objeciones: la incapacidad del arquetipo de manifestarse como tal y que el objetivo tal vez no sea «reconocer» modelos y mitos, sino decir que «son reconocidos como», dada su fuerza y variación ${ }^{56}$. Si la forma de una obra histórica es su ficción (White 2003: 122), sería absurda toda la encendida discusión por definir lo ficticio de aquello que no lo es; un contrasentido hablar de literatura e historia, de factualidad y posibilidad. Para el autor lo que importa es que la historia y la literatura cobran sentido de la misma manera, «dotando a lo que originalmente parece ser problemático y misterioso del aspecto de una forma reconocible porque es familiar. No importa si el mundo es concebido como real o solamente imaginado» (ibíd.: 138).

Por consiguiente, la configuración de una situación histórica — tramadoes «esencialmente una operación literaria, es decir, productora de ficción. Y llamarla así en ninguna forma invalida el estatus de las narrativas históricas como proveedoras de un tipo de conocimiento» (ibíd.: 115). En este punto, el filósofo e historiador norteamericano encontrará su mayor objeción en Paul Ricoeur, pues este reconoce, de partida, la disimetría entre el relato histórico y el de ficción «en cuanto al alcance referencial y a la pretensión de verdad de cada uno de los grandes modos narrativos» (Ricoeur 2008: 637), si bien considera a la ficción «una reserva de variaciones imaginativas» (ibíd.) también presente en la historia ${ }^{57}$, pero no dada únicamente y en primera instancia por la narración. Ricoeur distingue entre la elección de modelos explicativos y la construcción de la narración, para así conservar la especificidad de las opera-

de ellas-, pero es el caso de considerar los mitos históricos como falacia poética, adscritos o bien a una forma novelesca o bien a una forma cómica o a una forma trágica o a una forma irónica. Frye es su punto de partida para revisar la teoría de los tropos y traslada estos cuatro modos esenciales de exposición de un discurso o «estructura de trama mítica» a la (filosofía de la) historia del siglo XIX. El problema radica precisamente en que estos conceptos, entendidos de esta forma, flotan en una esfera totalmente acrónica, ahistórica, pues ni siquiera ingresan funcionalmente a una teoría de los géneros literarios, en cuanto formaciones históricas.

${ }^{55}$ Aquí White sigue a Frye: «las ficciones son, en parte, sublimaciones de estructuras míticas arquetípicas» (White 2003: 111).

${ }^{56}$ Otra objeción importante radica en el mero traslado de la terminología de Frye al discurso histórico, que limita las estructuras pregenéricas de trama, pero esto ya tiene que ver con reparos al modelo mismo de Frye.

${ }^{57}$ Me refiero a la imaginación a priori presente en el trabajo del historiador, según Collingwood, y que también es considerada por Danto al hablar de las lagunas del pasado abordadas por la narración a través de un trabajo de disposición e imaginación. 
ciones que sostienen la intención de verdad de la historia y sus estrategias explicativas. En este sentido, su distinción concuerda con la de Roger Chartier:

La precaución tomada tiende a evitar los malentendidos que, a partir de la constatación según la cual la historia, al igual que la ficción, moviliza tropos retóricos y formas narrativas, disolviendo [sic] la capacidad de conocimiento del discurso histórico en su simple narratividad (Chartier 2005: 74).

\section{II.2.3. El problema del referente}

¿Cómo defender la especificidad literaria frente a los diferentes modos de representación del pasado, si la ficción es un terreno que cada vez difumina más sus límites? ¿Recurrir al referente es, acaso, una salida plausible para devolver especificidad a la historia y comprender las conexiones que la literatura establece con sus contextos y recepciones?

White ha abogado por la igualdad de condiciones en que queda la novela frente a la historia en cuanto a la representación y la narración del pasado. Una delgada línea es la que separa y define a ambos discursos, que no tiene que ver ni con sus contenidos ni con sus procedimientos, es más — tal vez White lo lleva a un punto extremo, pero- a la historia le faltaría leerse a sí misma, sin perder de vista su dimensión ficticia; entendiendo por esto, tropológica, retórica $^{58}$.

Un defensor acérrimo de la pretensión de verdad en la historia es Paul Ricoeur, sostenida en una serie de procedimientos específicamente historiográficos (recurrir a los documentos) que han ido variando dependiendo de los modos de hacer y concebir la historia - como ocurre con la historia de la vida privada o la historia oral (Burke)-, pero que además, como bien dice Danto, están fuera de la historia, en su relación con los textos y con discursos de otras disciplinas. Cuando Ricoeur funda esta distinción en el referente, recurre a la manida y mal comprendida ventaja referencial de la historia respecto de la ficción.

Afirmar que las narrativas históricas remiten indiscutiblemente a un referente, mientras que las novelas de ficción no $^{59}$, implica un error de concepto. Si revisamos la teoría lingüística saussuriana, vemos que todo signo evoca una realidad no lingüística llamada referente, distinta al significado (Marchese y Forradelas 1989: 344). De las interpretaciones hechas a este concepto provienen las confusiones. Una de ellas es que el texto literario carece de referente, pero las revisiones a las teorías de la ficción permiten replantear el hecho de que el

${ }^{58}$ Es lo que ocurre en la tradición historiográfica cultural y política actual en Chile con la desclasificación de archivos pertenecientes al período de la Dictadura Militar.

${ }_{59}$ Como determinación y característica. O, que ese referente es de otro tipo, de otra índole. Algo así como el referente de la ficción/versus el referente de la historia. 
signo lingüístico tenga un referente «que hace que podamos comprender» (ibíd.) una existencia ficticia, que no remite a un mundo empírico, sino a un sistema-mundo de objetos no existentes, «que pertenecen a una ideología compartida o compartible» (ibíd.) ${ }^{60}$, lo cual quiere decir que podemos recurrir al referente como a una imagen alojada en nuestra cabeza.

Otra confusión frecuente se ha producido entre referente y referencia, esta última entendida como la realidad extralingüística a que remite todo signo lingüístico y que «no lo pone en relación directa con el universo de los objetos reales, sino con el mundo establecido — transformado - por el ámbito de las formas culturales e ideológicas de una sociedad determinada, ámbito muchas veces marcado por el sistema de la lengua» (ibíd.: 343-344), mientras que para Jakobson el referente es «la situación y el contexto» (ibíd.: 344) al cual envía el mensaje.

Revisando estas definiciones, todo discurso, todo enunciado, posee referente y referencia, como forma de existencia propia del signo lingüístico.

Una refutación importante al discurso histórico es la realizada por Roland Barthes en su ensayo «El discurso de la historia». En él observa a la historia a través de los dispositivos conceptuales de la teoría semiótica narrativa, con el objetivo de poner en evidencia los mecanismos discursivos, o shifters, que utiliza el historiador para «indicar en su discurso ${ }^{61}$ el acto por el cual lo profiere» (Barthes 1987: 37). Su análisis surge ante la duda sobre la pertinencia de mantener la distinción entre discurso poético, novelesco o de ficción y relato histórico en el marco de una «lingüística del discurso», que sería capaz de develar los rasgos que, en el discurso, harían de la historia garante de lo real.

El discurso de la historia presenta «indicadores» de escucha o testimoniales. Este shifter considera toda mención de fuentes y testimonios, toda alusión a una «forma de escuchar» del historiador que «recoge un "afuera" de su discurso y lo dice» ${ }^{62}$ (ibíd.: 38). Para Barthes este shifter no es pertinente al discurso histórico, pues se lo encuentra con frecuencia en la conversación y en algunos artificios compositivos de la novela ${ }^{63}$.

Barthes sigue a Jakobson para referirse a los signos del enunciante (o destinador) como uno de los problemas o estrategias discursivas centrales a la historia: «El historiador, sujeto vacío de la enunciación, se va llenando de

60 Un problema interesante en torno al referente se ha suscitado con la virtualidad del ciberespacio.

61 «Conjunto de palabras superiores a la frase» (Barthes 1987: 37).

62 Es común en los historiadores-etnólogos que utilizan fórmulas como «según he oído», «por lo que sabemos» (Heródoto) y que incorporan su experiencia personal (Michelet).

63 Lo curioso es que para Ricoeur las «anotaciones» (notas al pie que hacen referencia a las fuentes y los documentos, y que podemos equiparar al shifter de escucha), justamente, juegan un papel central en la caracterización y especificidad del discurso histórico (Ricoeur 2008: 328). 
predicados diversos destinados a fundarlo como una persona, provista de plenitud sicológica o, más aún (la palabra es una figura) de una capacidad» (ibíd.: 41). El enunciante puede «disponer ausentarse» de su discurso, creando la ilusión de que la historia se cuenta sola. Esta estrategia corresponde al discurso histórico «objetivo», en que el historiador no interviene, y que también utilizó la novela realista. Las conclusiones de Barthes (1987: 42) son drásticas: «A nivel del discurso, la objetividad —o carencia de signos del enuncianteaparece así como una forma particular de lo imaginario, el producto de lo que podría llamarse la ilusión referencial, puesto que el historiador sostiene que deja hablar solo al referente». Esto pone en evidencia contradicciones en una defensa del referente en la confrontación entre discurso histórico y ficción. El filósofo francés sentencia que:

La amenaza dirigida contra la pretensión referencial de la historia estaba contenida en la elección del modelo saussuriano en el plano de la semiótica general; evocamos ya las consecuencias para el tratamiento del discurso histórico de la exclusión del referente exigido por la constitución binaria del signo: significante-significado (Ricoeur 2008: 326) ${ }^{64}$.

Ricoeur defiende el lugar de la historia frente a la teoría semiótica del relato, que encuentra su mayor acogida y desarrollo en los estudios literarios atraídos, hacia una teoría de los signos lingüísticos que, concibiendo el lenguaje como un sistema de signos y de significación en lugar de una configuración establecida de significados, desplazó o suspendió, en palabras de De Man (1990: 19), «las barreras tradicionales entre los usos literarios y presumiblemente no literarios y [liberó] al corpus del peso secular de la canonización textual», afectando igualmente a la historia ${ }^{65}$. Esto ha suscitado un importante dilema para la historiografía, no en cuanto a la imposibilidad de hacer historia, porque la historia de las mentalidades o la microhistoria han demostrado lo contrario, sino en términos de los contenidos y los territorios del pasado que creía propios.

${ }^{64}$ Las defensas de la historia consideran que el modelo lingüístico utilizado ha sido inapropiado al discurso histórico y que este sería mejor comprendido a través de modelos alternativos «para los cuales el referente, cualquiera que sea, constituye una dimensión irreductible de un discurso dirigido por alguien a alguien sobre algo» (Ricoeur 2008: $327-$ 328) y que fuera capaz de explicar la referencialidad en el «régimen historiográfico». Pero esta propuesta nuevamente cae presa de las observaciones que hemos revisado en torno a la teoría lingüística; el modelo lingüístico no concibe signo alguno sin referente ni referencia. La historia adolecería, más bien, de una teoría historiográfica capaz de satisfacer sus necesidades conceptuales y resolver sus crisis epistemológicas (White 1987; Kellner 1989; Mali 2003; Danto 1989).

${ }^{65}$ Este argumento es desarrollado por Hayden White cuando indica que la historiografía asienta su tradición a través de «clásicos», con lo cual quiere decir que no está libre de canonizaciones ni de ser tendenciosa (White 2003: 122). 
La tesis de Ricoeur es que la referencialidad, en el régimen historiográfico, «no puede discernirse únicamente en el plano del funcionamiento de las figuras asumidas por el discurso histórico, sino que debe pasar a través de la prueba documental, la explicación causal/final y la configuración literaria» (Ricoeur 2008: 327-328) y no solo en la textualidad, como ocurre con la literatura. Esto implica un distanciamiento radical de lo que situaría a la literatura con su potencial de autonomía lingüística (o literariedad) - y referencial-.

La veridicción histórica se funda en la presencia de estos otros textos probatorios (documentos, archivos), pero también esta se pone en funcionamiento con los contenidos y el conocimiento generado por textos provenientes de otras áreas, como por ejemplo, una novela, incluso por contraste. La veridicción tiene que ver con el estatuto del discurso histórico «uniformemente aseverativo, verificativo», «ligado lingüísticamente a un privilegio de ser» (Barthes 1987: 45), por tanto, el discurso histórico no conoce la negación, a diferencia de la literariedad, que instala a la literatura en «el lugar donde se puede encontrar este conocimiento negativo sobre la fiabilidad de la enunciación lingüística» (De Man 1990: 22).

Este argumento supone algunas consecuencias, por ejemplo que el discurso «objetivo» sea un discurso esquizofrénico y el discurso histórico, psicótico (Barthes 1987: 45), porque «es incapaz de someter un enunciado a una transformación negativa» (ibíd.) y en ambos casos hay una censura de la enunciación, que desvía el discurso hacia el enunciado y el referente, pero sin que pueda ser asumido porque el historiador habría desaparecido, según veíamos unas líneas más arriba.

Precisamente, la literatura es ficción no porque se niegue a aceptar la «realidad», sino porque «no es cierto a priori que el lenguaje funcione según principios que son los del mundo fenomenal o que son como ellos» (De Man 1990: 23).

Barthes $(1981 ; 1987)$ toca muchos puntos centrales a la discusión, primero, que el referente — que nunca ha sido exterior - es exteriorizado por la historia (primero la res gestae, luego la historia rerum gestarum), segundo, este desplazamiento del referente encubre el desplazamiento del significado, que es confundido con el referente, el cual se relaciona de manera directa con el significante, mientras el discurso «encargado de expresar lo real, considera posible eliminar el significado, término fundamental de las estructuras imaginarias» (Barthes 1987: 48-49), «llenadas» por el lenguaje. El análisis deconstructivo de la estructura del discurso histórico constata que, a pesar de todo, este es elaboración ideológica e imaginaria. 


\section{II.2.3.1. Ficción y referente}

Lo que sigue no pretende ser, en ningún caso, una revisión exhaustiva de teorías de la ficción y los mundos posibles, solo quisiera tomar algunas ideas centrales de autores como Schmidt, Ohmann, Iser, Dolezel, Martínez y Pavel para comprender la ficción como «ficcionalización»-procedimiento al cual también está sometido el discurso de la historia, según las tesis que hemos revisado - y revisar cómo opera la noción de referente al interior de los mundos posibles, cuando estos entran en relación evidente con sus contextos extraliterarios inmediatos y pasados, especialmente en el género «novela histórica». El objetivo central es replantear la idea en torno a los grados en que la literatura se relaciona con sus contextos socio-históricos, entendidos como contingencia y pasado.

La teoría de los Actos de Habla, en un afán por instalar la dimensión pragmática en los estudios literarios, inhibió una de las potencialidades centrales al acto poético - sistematización y restricción de la teoría simbolista del lenguaje- convirtiéndolo en un macro acto de habla que en sí contiene innumerables actos de habla capaces de sostener el mundo configurado, pero - en términos de la teoría de los Actos de Habla_, con una fuerza ilocutiva disminuida (Ohmann 1987), con lo cual se transforman en quasi-actos de habla (Dijk 1987), que imitan una locación imaginaria. Estas proposiciones restarían fuerzas a la enunciación literaria para constituirse en acto por sí misma; entendamos con esto transformar la relación con los interlocutores o con los referentes. La teoría pragmática de los Actos de Habla, aplicados a la literatura, ha dejado a la ficción literaria en un estado de minusvalía, respecto de su injerencia en los entornos y su capacidad de intervención en los contextos ${ }^{66}$.

Con ello se perdieron de vista algunas potencialidades de la literatura: su capacidad comunicativa pero, sobre todo, su capacidad cognoscitiva, curiosamente rescatadas y reivindicadas por algunos autores deconstruccionistas, como Paul De Man y Hayden White. Es más, puede ser que «el impacto [de la ficción] en el mundo sea demasiado fuerte para nuestro gusto», dirá De Man y, por su parte, White fundamenta su teoría tropológica de la historia, en la creencia de que la literatura ¡«algo» nos enseña sobre la realidad! ${ }^{67}$.

66 La contraparte a esta perspectiva teórica fue hecha por la Estética de la Recepción, principalmente por H. R. Jauss con la incorporación de la dimensión histórica en la recepción y lectura de las obras.

67 «Así, decir que damos sentido al mundo real imponiéndole la coherencia formal que nosotros asociamos por costumbre con los productos de los escritores de ficción no invalida en forma alguna el estatus de conocimiento que adscribimos a la historiografía. Sólo invalidaría ese estatus si creyéramos que la literatura no nos enseña nada acerca de la realidad» (White 2003: 138). 
En términos generales, la ficcionalización, como regla de la comunicación estética, se sostiene teóricamente en la diferencia y relación de los mecanismos consentidos de «alejamiento» de lo real-inmediato, cuya mayor repercusión radica en la supresión del juicio de interpretación referencial (entendida como apelar a una exterioridad comprobable) o, en un mismo plano, suspender los criterios de verdad (verdadero/falso) y sustituirlos por criterios estéticos vigentes y sujetos a la convención. Al aceptar estas reglas los papeles de la comunicación se vuelven fictivos o se han ficcionalizado (Schmidt 1987: 203). En su sentido más amplio, podemos entender la fictivización como un proceso de alteridad, disociación o bifurcación de un yo (que emite un mensaje y que lo recibe), en el entendido de que no es el mismo y que ocurre una pérdida de identidad. Schmidt hablará de «estados de cosas fictivos» (ibíd.: 206), distinguiendo lo fictivo de lo engañoso y sugiriendo que la «fictivización» puede ser aplicada a cualquier objeto del mundo y que, de ser reconocida por el receptor, «lleva a no verse en la obligación de referir los mundos textuales al marco de referencia de los modelos de realidad, válidos para el productor real y para el receptor real, como es el caso de la comunicación no literaria» (ibíd.).

En el marco de las situaciones de la comunicación literaria y estética, fundadas en la regla $\mathrm{F}$ de ficcionalización, Schmidt propone hablar de mundo fictivo. El mundo fictivo corresponde al mundo textual en su conjunto, más allá de proposiciones aisladas de los textos literarios; el receptor «pone en correlación» el mundo fictivo con el texto cuando observa la regla $\mathrm{F}$, por lo cual afirma la complejidad referencial representada por el texto en su conjunto, dando una plataforma para el despliegue de una teoría de la narración ${ }^{68}$. Por consiguiente, interesa mucho destacar que:

La hipótesis de que la regla $\mathrm{F}$ conduce a la constitución de mundos textuales fictivos, no excluye que una serie de aserciones contenidas en los textos literarios o partes enteras de mundos textuales puedan muy bien ser puestos en relación con el marco de referencia de la realidad de experiencia de los receptores (así, por ejemplo, en las novelas históricas) (Schmidt 1987: 206).

Las fronteras entre el mundo actual y los mundos ficcionales son «imprecisas, históricas y culturalmente variables» (Pavel 1997: 18), pero, sobre todo, permeables, lo cual quiere decir que el traspaso de los límites ocurre de ambos $\operatorname{lados}^{69}$. Esta aclaración es central para comprender que no existe una relación jerárquica entre los «mundos» y que dichas contaminaciones hablan de una necesidad mutua de interconexión:

\footnotetext{
${ }^{68}$ Vemos que constituye un argumento circular, pero muy prolífica para el estudio de la ficción, la relación entre teorías narrativas y mundo fictivo.

${ }^{69}$ Aunque algunos autores precisan que dicha contaminación ocurre solo a nivel sicológico; porque no se trata de una suspensión de la incredulidad, sino de un fingimiento de la creencia que, a su vez, potencia una actitud (Walton en Garrido 1997: 18).
} 
Determinados elementos del mundo actual - como los mitos o los poemas épicos - que terminan ficcionalizándose, y viceversa: entidades contenidas en los mundos de ficción - como parábolas, profecías, novelas de tesis, etc.sobrepasan ampliamente los límites de lo ficcional y acaban influyendo sobre el mundo real (Garrido 1997: 18).

El acceso a los mundos posibles de la ficción es posible gracias a una compatibilidad entre estos y el mundo actual, regida por los géneros literarios ${ }^{70}$. Podemos acceder a los mundos ficcionales por su proximidad al mundo actual, que a su vez «siempre está presente en los mundos construidos a través de los textos literarios (aunque solo sea como referencia para justificar su distanciamiento de la realidad) y que provee de experiencias y conocimiento al lector, quien las proyecta sobre los mundos de ficción». Esto supone «tomar en serio» la ficción (Pavel 1997: 20) como algo real y reducir al mínimo la distancia entre ambos mundos. Esta postura tiene como correlato la experiencia síquica «inapelablemente real» en que consiste la vivencia de los mundos proyectados en los textos (Martínez 1997: 165; Garrido 1997: 21).

El alegato a favor de la referencia en la ficción conduce a la cuestión de la verdad en literatura, aceptada como verdad literaria o verdad estética en autores como Dolezel, Mignolo o Martínez. La existencia ficcional funda tanto una verdad ficcional como una función autentificadora (Dolezel en Garrido 1997: 22) propia de los actos de habla del narrador, que hace referencia a un mundo construido, precisamente, por dichas afirmaciones. Dolezel adopta una perspectiva anti esencialista de los mundos ficcionales al afirmar que estos han «de verse como resultado de la actividad textual» (ibíd.) y no anteriores ni preexistentes a ella, por lo cual las referencias tampoco anteceden ${ }^{71}$.

La verdad literaria se identifica con el concepto de «coherencia interna» del texto narrativo, por la cual el narrador se juega su credibilidad. Esta «verdad interna» al mundo del texto, avalada por él, puede entrar en contradicción con el mundo actual (Garrido 1997: 22), hecho que se intensifica en la ficción de archivo $\rightarrow$ novela mito-histórica por su carácter revisionista y contra oficial. Es posible reclamar la autonomía completa de los mundos ficcionales, pero solo como un primer estadio en los modos de comportarse dichos mundos y

70 Hay géneros que presentan una mayor o menor compatibilidad como la historiografía, la biografía y los géneros periodísticos. Me distancio de la idea de una compatibilidad absoluta, según Ryan (Garrido 1997: 19) porque aparece inevitablemente la refutación al realismo (Barthes 1987). Los géneros literarios presentarán mayor o menor accesibilidad al mundo posible, las diferencias estarán dadas por los distintos tipos de ficción (ficción de lo real, ficción histórica y realista, fabulación histórica).

71 Esta distinción retoma el problema del referente y su pseudo exterioridad o mal comprendida exterioridad. Por este motivo, el autor sugiere hablar de literatura referencial y no necesariamente de literatura mimética (Dolezel en Garrido 1997: 70). 
de relacionarse con los mundos actuales ${ }^{72}$. El hecho de que la «creación» de los objetos ficticios «se lleve a cabo en el mundo actual del autor y sus lectores» (ibíd.), pero exista en el mundo actual del narrador, garantiza no solo la autonomía del mundo ficcional, sino también su conexión con el mundo real. Pero esta visión aún sigue concibiendo a lo real como productor de lo imaginario y a la ficción como dependiente y subsidiaria. Tampoco está considerada la proyección de lo imaginario sobre lo real o, entendido de otro modo, de qué manera la ficción influye, se proyecta, sobre los mundos actuales ${ }^{73}$.

La cualidad específica de la literatura es la configuración de un Campo de Referencia Interno (CRI) o mundo imaginario, integrado por entidades relacionadas entre sí (acontecimientos, personajes, ideas, espacio, tiempo). Esto no excluye que pueda incorporar elementos provenientes de un Campo de Referencia Externo (CRE) (personajes históricos, referencias geográficas, etc.) y conducir a una interrelación esporádica de ambos campos, dando lugar a la aparición de «enunciados de doble dirección» (Harshaw, en Garrido 1997: 27), o de referencia en ambos mundos, en el texto.

Esta perspectiva admite una relación gradual y variable de la ficción con sus contextos histórico-sociales, en cuanto contingentes o pasados, dirigida por la característica peculiar de las obras literarias: la literatura estaría hecha de casos particulares.

Quisiera cerrar aludiendo a dos nociones que consideran la relación indesmentible entre historia y ficción, junto a la reivindicación cognoscitiva ${ }^{74}$ de esta última. Se trata de la referencia cruzada y la evidencia conceptual. La primera de ellas, propuesta por Ricoeur, decanta en el problema del tiempo: de esta imbricación en la que se «conjugan la representancia ${ }^{75}$ del pasado mediante la historia y las variaciones imaginativas de la ficción, sobre el fondo de las aporías del lenguaje» (Ricoeur 2008: 917) surge el tiempo humano ${ }^{76}$. Este hecho

72 Dolezel (Garrio 1997) aboga por esta autonomía. Lo mismo se desprende de Martínez Bonati (1997) al ubicar a la ficción en otro plano ontológico respecto de la realidad.

${ }^{73}$ Una de las mayores defensas de la ficción la hizo el existencialismo (Sartre, Camus, Merleau-Ponty) y que sería continuada por autores como Herbert Marcuse o Antonio Cándido y postestructuralistas como Paul De Man, en un tono deconstructivo.

${ }^{74}$ En términos tanto empíricos, como sensoriales; imaginarios e intelectivos.

75 Paul Ricoeur hará la distinción entre representación y representancia, la primera de ellas - como revisamos al inicio del capítulo - se vincula con la mimesis, mientras que la segunda introduce la distancia necesaria «entre el pasado representado y las formas discursivas necesarias para su representación». (Chartier 2005: 76). La representancia será propia de la historia y corresponde a la representación como operación, a diferencia de la representación como objeto. Ambas presentes en el discurso histórico (Chartier 2005: 74).

${ }^{76}$ No hay que olvidar que el eje de los planteamientos de Ricoeur son la narración y el tiempo. En este sentido, historia y ficción resolverían el problema fenomenológico de la concordancia discordante del tiempo; entre las aporías agustinianas y de la progresión del ahora, hasta el orden lineal del tiempo aristotélico de la trama, instancias que Ricoeur ubica 
supone la ficcionalización de la historia ${ }^{77}$ y la historización de la ficción ${ }^{78}$, tal vez por motivos bastante discutibles, pero que encierran una conclusión significativa para el análisis, a saber, la imbricación de los planos por la imaginación, aunque se siga afirmando la resistencia de la forma literaria y retórica a la pulsión referencial del relato histórico hacia el pasado (Ricoeur 2008: 325), afirmación que queda desmentida, de partida, con la novela-histórica (aunque Ricoeur argumentaría que, lo que hace este género literario, es ajeno a la veridicción y la documentación y no configuraría un tiempo histórico, o real).

La consecuencia más significativa de la referencia cruzada es reconocer una de las funciones de la ficción: «liberar retrospectivamente ciertas posibilidades no efectuadas del pasado histórico». «El [cuasi] pasado de la ficción se convierte así en el revelado de los posibles escondidos en el pasado efectivo» (Ricoeur 2008: 916).

La libertad de la ficción, por cierto, no radica en la libertad, respecto de los documentos, porque dicha libertad es relativa: también los usa, pero no los respeta, necesariamente.

Danto hará una distinción muy lúcida entre relato histórico y relato de ficción a través del concepto de evidencia. Sin «evidencia adicional» (fuentes de la historia-como-registro) la narración «flota en el aire» y sería ficción (Danto 1989 [1965]: 71). Este argumento no lo distancia, considerablemente, de Ricoeur, pero más adelante completa: «Seguramente esto nos ayuda a ver la diferencia entre las narraciones y los datos que tenemos de ellas (una narración de ficción es la que sólo requiere una evidencia conceptual» (ibíd.: 72).

en las antípodas de la configuración y experiencia humana del tiempo. La historia reinscribe el tiempo de la narración en el tiempo del universo, mientras que la ficción transmite otras experiencias del tiempo, configurando temporalidades inéditas (que es lo que observa en Thoman Mann, Virginia Woolf o Marcel Proust). Las mayores objeciones a la propuesta de Ricoeur provienen de estimar realistas a la historia y el tiempo histórico, solo por el hecho de que «la historia somete su cronología a la única escala de tiempo, común a lo que se llama la "historia" de la tierra, la "historia" de las especies vivientes, la "historia" del sistema solar y de las galaxias» (Ricoeur 1996: 903), especificidad del modo referencial de la historiografía. La primera objeción tiene que ver con que estas temporalidades bien pueden estar asociadas al mito (tema a revisar en el capítulo III); la segunda, con que ya el concepto 'historia' es un dispositivo creado por la mente humana para configurar una temporalidad asible al hombre, lineal, causal y controlable.

${ }^{77} \mathrm{La}$ ficcionalización de la historia ocurre cuando se entrecruza la función de lo imaginario en la perspectiva del pasado «tal como ha sido», sin debilitar su perspectiva realista, o sea, esencialmente histórica. La reefectuación (la presencia del «efecto de discurso» que es parte de la literatura) y el acontecimiento fundante corresponden a los ingresos de la ficción en la historia (Ricoeur 1996: 909).

${ }^{78} \mathrm{El}$ argumento de la historización de la ficción es sumamente débil, se sostiene en el carácter de cuasi pasado del pasado de la ficción. Esto es, por el hecho de configurar un discurso en pasado (el pasado de la voz que narra), la ficción es historizada en la medida que «el pasado» (histórico, real, efectivo — y no cuasi) le pertenece a la historia. 
La evidencia conceptual permite construir narrativas más complejas, porque supone un acervo más extenso, «quizá más fiable» (ibíd.: 73) que el de la evidencia documental. Si bien el autor designa el término como aplicable a la historia, no es menos cierto afirmar que la ficción sostiene sus mundos en la evidencia conceptual, dada a través de la configuración poética.

\section{BIBLIOGRAFÍA CITADA}

Aristóteles (1974). Poética, ed. trilingüe por Valentín García Yebra. Madrid: Gredos.

Barthes, Roland (1981). «El mito, hoy», en Mitologías. México: Siglo XXI.

Barthes, Roland (1987). «El discurso de la historia», en El susurro del lenguaje: más allá de la palabra y de la escritura, trad. C. Fernández Medra. Barcelona: Paidós.

Chartier, Roger (2005). El presente del pasado. México: Universidad Iberoamericana, Departamento de Historia.

Collingwood, Robin G. (1965). Idea de la historia, trad. Edmundo O'Gorman y Jorge Hernández. México: Fondo de Cultura Económica.

Croce, Benedetto (1967) [1912]. Breviario de estética. Madrid: Espasa Calpe.

Danto, Arthur (1989) [1965]. Historia y narración. Barcelona: Paidós.

De Man, Paul (1990). La resistencia a la teoría. Madrid: Visor.

De Micheli, Mario (1999) [1979]. Las vanguardia artísticas del siglo XX. Madrid: Alianza.

Dijk, Teun A. van (1987). «La pragmática de la comunicación literaria», en José Antonio Mayoral (comp.), Pragmática de la comunicación literaria. Madrid: Arco/Libros, pp. 171-194.

Dijk, Teun A. van (1998). «El discurso como interacción en la sociedad», en Texto y contexto: semántica y pragmática del discurso. Madrid: Cátedra.

Eagleton (2007) [1983]. Una introducción a la teoría literaria. México: Fondo de Cultura Económica.

Eichembaum, Boris (1970). «La teoría del método formal», en Tzvetan Todorov, Teoría de la literatura de los formalistas rusos. México: Siglo XXI, pp. 21-54.

Garrido, Antonio (1997). «Teorías de la ficción literaria: Los paradigmas», en Teorías de la ficción literaria. Madrid: Arco/Libros, pp. 11-40.

Genette, Gérard (1989). Figuras III. Barcelona: Lumen.

Genette, Gérard (1993). Fiction \& diction. New York: Cornell University Press.

Jauss, Hans R. (1976) [1967]. «La historia literaria como desafío a la ciencia literaria», en La literatura como provocación. Barcelona: Península, pp. 35-114.

Kellner, Hans (1989). Language and historical representation. London: The University of Wisconsin Press.

Kermode, Frank (1983). El sentido de un final. Barcelona: Gedisa.

Kushner, Eva (1994). «Articulación histórica de la literatura», en François Perus (comp.), Literatura e historia. México: Instituto Mora, pp. 165-187.

López Griega, Luisa (1994). La retórica en la España del Siglo de Oro. Salamanca: Universidad.

Lozano, Jorge (1987). El discurso histórico. Madrid: Alianza.

Mali, Joseph (2003). Mythistory. The making of a Modern Historiography. Chicago: The University of Chicago Press. 
Marchese, A. y Joaquín Forradellas (1989). Diccionario de retórica, crítica y terminología literaria. Barcelona: Ariel.

Martínez Bonati, Félix (1983) [1960]. La estructura de la obra literaria. Barcelona: Ariel.

Martínez Bonati, Félix (1997). «El acto de escribir ficciones», en Antonio Garrido Domínguez (comp.), Teorías de la ficción literaria. Madrid: Arco/Libros, pp.159-170.

Munz, Peter (1990) [1983, original en inglés]. «La idea de "Ciencia Nueva" en Vico y Marx», en Giorgio Tagliacozzo (comp.), Vico y Marx, afinidades y contrastes. México: Fondo de Cultura Económica, pp. 13-29.

Ohmann, Richard (1987). «Los actos de habla y la definición de literatura», en José Antonio Mayoral (comp.), Pragmática de la comunicación literaria. Madrid: Arco/Libros, pp. 11-34.

Pavel, Thomas (1997). «Las fronteras de la ficción», en Antonio Garrido Domínguez (comp.), Teorías de la ficción literaria. Madrid: Arco/Libros, pp. 171-179.

Perus, Francoise, comp. (1994). Historia y literatura. México: Instituto Mora.

Ricoeur, Paul (1998-1999). Tiempo y narración. México: Siglo XXI.

Ricoeur, Paul (2008). La memoria, la historia, el olvido. Buenos Aires: Fondo de Cultura Económica.

Schaeffer, J. M. (2002). ¿Por qué la ficción? Madrid: Lengua de Trapo.

Schmidt, Siegfried (1987). «La comunicación literaria», en José Antonio Mayoral (comp.), Pragmática de la comunicación literaria. Madrid: Arco/Libros, pp. 195-212.

Staiger, Emile (1966). Conceptos fundamentales de poética. Madrid: Ediciones Rialp.

Verdenius, W. J. (1981). Doctrina de Platón sobre la imitación artística, Ximena Ponce de León (trad.). Santiago: Universidad de Chile, Departamento de Filosofía (Serie Traducciones.).

White, Hayden (1992). Metahistoria: La imaginación histórica en la Europa del siglo XIX. México: Fondo de Cultura Económica.

White, Hayden (2003). El texto histórico como artefacto literario. Barcelona: Paidós.

White, Hayden (2011). «La supresión de la retórica en el siglo XIX», en La ficción de la narrativa. Buenos Aires: Eterna Cadencia

Fecha de recepción: 2 de noviembre de 2015

Fecha de aceptación: 25 de enero de 2017. 